Revue Française de Civilisation Britannique

XXI-2 | 2016

Economic Crisis in the United Kingdom Today: Causes and Consequences

\title{
Reasoning through Crisis: Crisis, Incommensurability and Belief
}

La raison permet-elle de penser la crise? Crise, incommensurabilité et croyance

James Connelly

\section{CpenEdition}

Journals

Electronic version

URL: http://journals.openedition.org/rfcb/1069

DOI: $10.4000 /$ rfcb. 1069

ISSN: 2429-4373

Publisher

CRECIB - Centre de recherche et d'études en civilisation britannique

Electronic reference

James Connelly, « Reasoning through Crisis: Crisis, Incommensurability and Belief », Revue Française de Civilisation Britannique [Online], XXI-2 | 2016, Online since 10 September 2016, connection on 01 May 2019. URL : http://journals.openedition.org/rfcb/1069 ; DOI : 10.4000/rfcb.1069

This text was automatically generated on 1 May 2019.

\section{c) 89}

Revue française de civilisation britannique est mis à disposition selon les termes de la licence Creative Commons Attribution - Pas d'Utilisation Commerciale - Pas de Modification 4.0 International. 


\section{Reasoning through Crisis: Crisis, Incommensurability and Belief}

La raison permet-elle de penser la crise? Crise, incommensurabilité et croyance

James Connelly

\section{Introduction}

1 This paper draws on Thomas Kuhn's The Structure of Scientific Revolutions, ${ }^{1}$ but it is neither an exposition nor a critique of that book. Rather it uses certain key concepts from it as a springboard for some reflections of my own concerning the nature of crisis. Kuhn started out as a physicist who only later became an historian and philosopher of his own discipline upon being triggered by the recognition that scientists had typically failed to understand their own history, in particular the nature of the progression from one significant event to another. Kuhn was not entirely alone in seeing the need for a revision of the history of the natural sciences. Herbert Butterfield, for instance, who wrote on the history of science and also memorably on the whig interpretation of history drew attention to 'the tendency in many historians to write on the side of Protestants and Whigs, to praise revolutions provided they have been successful, to emphasize certain principles of progress in the past and to produce a story which is the ratification if not the glorification of the present.'2 And R.G. Collingwood, writing in the mid to late 1930s made very much the same points as Kuhn in his theory of metaphysics as the science of uncovering absolute presuppositions and his analysis of change and progress in science and other disciplines. ${ }^{3}$

2 The key term that Kuhn employed - rich in ambiguity - was, of course, paradigm; but for my present purposes the focus will be equally on the inextricably intertwined concepts of normal and revolutionary science, and one of the concepts central to the latter: crisis. My comments consider whether crisis necessarily constitutes a break in continuity or practice, together with our understanding of that practice, thereby generating an inability to 'think through' crisis (the radical rupture thesis), or whether crisis can be conceived in an evolutionary fashion as a dialectical progression in which tensions and 
oppositions do not necessarily signify (or result in) a breakdown of the system or our understanding of it (the dialectical thesis). One of the underlying questions to be considered is precisely how far the analogy between natural science and politics is valid. Here my purpose is primarily to explore the issue and to raise questions rather than to provide concrete answers.

\section{Crisis and Progress}

3 The Kuhnian schema, extended to include politics, can be summarized thus: Normal science or politics exists within a paradigm; emergent tensions and anomalies lead to crisis in that paradigm; this leads to a period of revolutionary science or politics; there is a resolution of crisis; there is a reversion to normal science or politics; until the next time....

4 It is clear that in Kuhn's characterisation, crisis is counterposed to a conception of progress or expected historical continuity. At the minimum this will be constituted by a sense of discontinuity in what would otherwise have been (or expected to have been) the case. At maximum it will be constituted by the sense of a break or threat to the continuation of a tradition or established set of practices.

5 Crisis is often thought of as simply equivalent to catastrophe, but such a conception not only deviates from the root meanings and associations of the word, but also leads us away from its relationship with progress in science or politics. Not only should we ask whether crisis can lead to progress, but we should also ask whether crisis is a necessary part of progress. If the latter claim is true, it contradicts the view of smooth continuity in progress and development. Progress and development on this view presuppose, as part of continuity, threats to continuity in the form of internal strains leading to crises leading to resolution leading to progress. Progress, in other words, is not identical with smooth development. As Collingwood remarked,

The dynamics of history is not yet completely understood when it is grasped that each phase is converted into the next by a process of change. The relation between phase and process is more intimate than that. One phase changes into another because the first phase was in unstable equilibrium and had in itself the seeds of change, and indeed of that change. Its fabric was not at rest; it was always under strain. ${ }^{4}$

6 Progress and development, then, occur not in spite of strains and crises but through them and, I shall argue, because of them. But it needs to be inquired how we can characterise the idea of progress itself. Surely, it might be suggested, if we are to speak intelligibly of progress we have to presuppose some conception of the end towards which that development is tending and against which we can measure the pace and rate of progress? Does progress, that is, necessarily presuppose (implicitly or explicitly) a telos? In science the telos is typically held to be one of more complete explanatory power: this is, in principle, possible to determine, and it serves as a regulative ideal for the scientific endeavour. ${ }^{5}$ For politics, a telos is much more problematic. If there is a telos in history then politics, as an activity taking place historically, is included somehow in that telos. The key question is what is meant by such a telos in history - is it something akin to historical determinism or something more innocuous and less deterministic? Another meaning of telos would be an ideal which is not in the process of being deterministically realised, but which is understood as the inevitable goal of an activity. In science - or at 
least in some of the branches of the sciences - it is intelligible to set as a goal the ideal of a complete explanatory system and to regard anything short of this as a sign of the, as yet, defective incomplete nature of the science, and the effort to attain this as its ideal. But in politics such an ideal - the ideal of a complete system of interlocking societal goals analogous to the ideal of a complete explanatory scheme in science - is either unintelligible or could only be made intelligible through force, imposition, oppression and control. The idea of a completely intelligible political world or of a completely controllable political world are both forms of telos. The claims made in the one are bound up with those made in the other: the latter presupposes the former and the former encourages the latter which lives by the myth of complete intelligibility, striving to make reality fit its imposed pattern, by force if necessary rather than admit that the myth was indeed a myth.

\section{Normal politics vs revolutionary politics}

7 Assume, for the sake of argument, that Kuhn is broadly correct about the nature of normal and revolutionary science; can we reasonably suppose that there can be a 'normal' politics akin to 'normal' science? And a 'revolutionary' politics akin to 'revolutionary' science? The notion of normal science implies relative stasis at a given point, a broad agreement on fundamentals of inquiry, on a constellation of agreed presuppositions and working practices. Kuhn states that 'Though intrinsic value is no criterion for a puzzle, the assured existence of a solution is' and that 'One of the things a scientific community acquires with a paradigm is a criterion for choosing problems that, while the paradigm is taken for granted, can be assumed to have solutions. ${ }^{6}$ We might wish to revise this view to some extent by arguing, as Collingwood did, that the appearance of stasis is illusory, an illusion produced by the snapshot of the moment, and that beneath the surface there will always be tensions, strain and incoherence. ${ }^{7}$ However, this does not undermine Kuhn's point, which is that, at a given time or period, and not only for heuristic purposes, but in scientific practice itself, there is sufficient overlapping agreement on a sufficient number of fundamentals for us to talk intelligibly of the contrast between normal science so conceived and revolutionary science (in which these characteristics are absent). Further, he would agree with Collingwood that science can and will exhibit strains and tensions as its explanatory fabric proves inadequate to what is required of it, and hence it enters a pre-revolutionary stage of crisis. Everything moves, but not at an equal pace; and there is a valid contrast to be drawn between science in its different phases - not all phases are alike.

Our primary concern, however, is not with science, but with politics and civilisation. We might accept that a Kuhnian account works for science: but is it an appropriate way of characterising politics? My answer is in the affirmative. Yes: there can be a normal politics or 'politics as usual:' but what is politics as usual or 'normal' politics?' 'Politics as usual', in the environmental context, for example, refers to a deeply entrenched approach to the economy, economic growth, and economic and political interests, together with scepticism concerning environmental policy, especially where it is felt to be a brake on growth. ${ }^{9}$ This form of politics does not necessarily imply active hostility to the environment, but it does imply relative indifference and the relegation of the environment to a secondary concern. The structure of 'politics as usual' comprises an overlapping set of deep presuppositions with a lexical ordering between levels of 
presuppositions and commitments, the structuring effects of power and influence, and the limits of bureaucratic rationality. On this view, the actions of government are an expression of underlying structures of power and influence, basic beliefs and administrative stasis. Mid-way between observable action and deep presuppositions lie approaches to tactics and strategy, manipulation and structuring of choices, and the shaping of the political opportunity structure.

9 Power is obviously important: at the deepest level lies the power of action-guiding presuppositions which are unquestioned and rarely challenged. At the next level there is the ability to shape and manipulate public debate through reputational power, or the implicit threat arising from the belief that political actors can access other forms of power if they wish. Finally, there is explicit observable power. Power operates on all these dimensions: they are not mutually exclusive but overlap, and differ in efficiency. For instance, it is more efficient to employ reputational power to manipulate the political agenda than to rely on explicit threats or physical force; and where the political agenda is founded on deep presuppositions ensuring prior agreement on fundamental ends, that is more efficient still. ${ }^{10}$

10 Thus a political actor can rely on reputation and implicit threat to achieve success in agenda manipulation. This is supplemented by the underlying constellation of presuppositions which absolves them of the need to argue their case explicitly because it is always already the default position. Only challengers to the status quo have to seriously argue their case, whereas its defenders are rarely required to provide more than a minimal level of argument. On this view, therefore, defenders of the political and economic status quo possess an inbuilt advantage either because no one questions the desirability of economic growth (as an end), or of roads, planes, trade and industry (as means); or, if these are questioned, the ensuing questioning is at best superficial. In this world, to be real is to be measurable; whatever is not measurable is not real; and the approved medium of measurement is GDP. In such 'debates' a conclusion is swiftly reached that, although hypothetical cases might exist where economic considerations are not paramount, in practice unlimited economic growth is an unqualified good. At this point all that then remains of policy debate is discussion of means, location or timing: when or where, rather than whether; more or less (rather than not at all); and hence opportunities for manipulation of decisions through the cunning use of pre-constrained choices open up nicely for policy makers wedded to the status quo.

11 'Politics as usual', then, concerns a set of presuppositions within which deep presuppositions (taken for granted in political/economic argument) can be distinguished from surface presuppositions (relatively open to question). Surface presuppositions typically concern means not ends; deep presuppositions tend to concern ends, not means. Relations between these presuppositions are governed by a 'lexical' ordering in which certain conditions having to be satisfied before others can come into play. For 'politics as usual', once the conditions for ensuring economic growth are satisfied, environmental considerations can be considered, but not vice versa. Therefore, if environmental protection is at the expense of economic growth it should not be pursued; if it promotes economic growth it should be pursued; if it has no palpable effect on economic growth it might be pursued if desired.

Debates surrounding climate change, energy, rail, roads and aviation policy take place within this framework, where two of the presuppositions of 'politics as usual' are the desirability of economic growth and belief that the relationship between environment 
and economy is typically a zero sum trade-off. The second presupposition is slightly more subtle than this, in that environment and economy are not necessarily assumed to clash, but where they do (and they usually will), the economy should be prioritised. Both might co-exist in a green economy pursuing sustainable green development, but the implicit proviso is that this so only while there is no opposition between them. It is revealing that 'green growth', the 'green economy' and so on are typically promoted not as green qua green, but as good for the economy: again, environmental values are subordinated to economic values. And economic values are assumed to be ends in themselves, predicated on a perception of 'the economy' as an exogenous reified entity, as distinct from any sense that the economy thus conceived is merely an abstraction from the multitudinous actions and transactions constituting distinct but inseparable parts of the totality of activities in a society.

'Policy making as usual' tends to be conducted incrementally. Incrementalism both describes how things happen and prescribes a model for rational decision making. Environmental issues, although their salience in public and political consciousness varies, have over time built up an institutionalised footing. They have become institutionally embedded, with the consequence that they operate within the bounds of the structural presuppositions of bureaucracies. Institutionalisation - the existence of agencies and departments - possesses the clear advantage of providing a ready-made structure within which policy responses can be channelled. However, along with inherited techniques for dealing with issues, problems tend to be defined in ways which only allow solutions that accord with prevailing political and administrative arrangements. The advantage of institutionalisation is at the same time its disadvantage because of the limits of the 'administrative mind' in which policy makers typically pay attention only to problems open to technological and administrative solutions. ${ }^{11}$ 'Rational' administration presupposes a view of progress within which some approaches are regarded as reasonable and others are not: within this frame, responses to environmental problems are often piecemeal, because taking a holistic view would challenge presupposed views of economic and industrial development. Any form of serious or radical environmentalism challenges this because it implies that the presupposed notions of 'development' and 'progress' may in themselves be the problem. As a result, problems cannot readily be admitted to be systemic crises but rather have to be presented as a series of manageable, soluble and more or less separable problems packaged in ways which match the 'functional differentiation of the administrative apparatus. ${ }^{{ }^{12}}$ Doubtless there is something to be said for reframing problems to admit of practicable solutions: it would be absurd to dismiss the importance of incrementalism, bounded rationality, and the constraints of the administrative mind. But taking environmentalism seriously presents a serious challenge to those limits and the presuppositions which sustain them. ${ }^{13}$

14 Normal politics on this view is like normal science. But assumptions can be powerful without being true - and that might be the case here. There might be no solution within normal politics; all we might have is the reassuring belief that there is a solution, thereby masking the deeper need for political change.

\section{Crisis in hope, expectations, legitimacy}

One of the characteristics of political crisis is a crisis in hope. In such a crisis, hope might be lost or it might become irrationally all-embracing: because we hope for nothing we 
hope for everything - a deus ex machina; and because we hope for everything, we are in fact hoping for nothing concrete in particular. In a crisis expectations become uncertain because we no longer know which cause produces which effect: the controls, buttons and levers are all in a different place and we don't know what, if anything, any of them does anymore.

Normal politics (politics as usual) is based on tacit premises and unarticulated practices; rules (both constitutive and regulative); the ability to recognise the present through its aetiology, its 'how it came to be.' The obvious contrast is revolutionary politics, with its attendant characteristics: the absence of rules, a loss of tacit understanding, the inability to recognise the present through understanding how it came to be. There is a parallel here, in our ability (or its absence) to read the present in the tests conducted on chess grandmasters which that they can remember any chess configuration shown to them, often with the briefest of glances, but, only if the position they are shown is the outcome of a possible sequence of real, rational chess moves. Where they are asked to remember chess configurations which are random, that is, lacking an intelligible history, they are typically unable to do so.

Kuhn observes that when confronted by even 'severe and prolonged anomalies', although scientists 'may begin to lose faith and then to consider alternatives, they do not renounce the paradigm that has led them into crisis'. He continues by observing that 'once it has achieved the status of paradigm, a scientific theory is declared invalid only if an alternate candidate is available to take its place'. ${ }^{14}$

The point about crisis is that there needs to be a resolution. But on the other hand, the point about crisis as experienced is that we can't be sure there is, can or will be a resolution. There is a crucial problem of not knowing whether the crisis will or can be resolved. Kuhn's point is that it can only be resolved when an alternative becomes available, but whether such an alternative will emerge is, in principle, a moot point. Crisis could, therefore, in such a case be permanent. A resolution does not have to be a violent revolution in the sense in which this is used in revolutionary politics. Another way of phrasing this is to say that there can be a dialectical resolution. But the challenge is that of having to call across the chasm. This we have to do where there are issues of incommensurability and incompatibility and its difficulty depends on how radical these issues are. A related point is that we need to ask whether crises within or between paradigms are the same as crisis of the tradition or historical continuity itself.

Directly linked to this point is the relation between criticism and crisis. The two stand and fall together, but in what way? In a crisis critical thought is required and thought is critical. But what of the notion of something as critical? Is this the same as its being important? And this raises again our opening question of whether it is possible rationally think one's way through a crisis, or whether this possibility is precluded by the nature of crisis itself. The meta problem here is that in times of crisis there might be no rules governing critical thinking or criticism; and this might be taken to imply that imply that therefore critical thinking itself becomes impossible. A related question is whether criticism itself is borne of crisis, and only applicable in crisis, or whether it is only possible in normal circumstances. This would lead to the paradox that while it is only possible under normal circumstances, it is especially required in revolutionary circumstances. That would be an intriguing and vicious irony. 


\section{Leadership and legitimacy} experts and the workings of the administrative mind. Crisis, on the other hand, perhaps requires Schmittian leadership, if we may dare call it that. By Schmittian I mean the need for leadership in circumstances in which 'normal' politics has broken down, circumstances in which agreement is elusive or impossible because of the absence of shared presuppositions and hence a situation in which the sovereign determines meaning in the absence of an authoritative cognitively grounded statement of meaning, and in which the sign of the sovereign is lies precisely in the ability to do so. The point about Schmitt's view is that he directly addresses the idea of crisis and insists that in a crisis the very grounds of reasoning are absent and the only way of cutting through to re-establish a new normality is for the sovereign to decide, a decision necessarily grounded on nothing other than the sovereignty of the sovereignty. 'For a legal order to make sense, a normal situation must exist, and he is sovereign who definitely decides whether the normal situation actually exists. ${ }^{15}$

Maybe, of course, we do not need to go so far. Whether one takes Schmitt's decisionistic account of sovereignty and the exception literally or figuratively, one can take from it the idea that it describes a politicised version of Kuhn's account of science in crisis. And what is the way out of crisis? We answer 'leadership', and when asked for clarification we say we seek 'cognitive leadership': the way out of crisis, if there is one, is through cognitive leadership. What is cognitive leadership? It is the ability to conceptualise and reconceptualise problems in such a way as to establish new ways of configuring discipline or reshaping a politics. In politics it includes the ability to frame power and interests in such a way as to show interested parties that where they might previously have appeared to be opposed, in fact they are not. Such an ability, should anyone possess it, is clearly important and possibly necessary in a crisis. It should be noted that what is suggested here is not the promotion of sophistry or propaganda, but rather the ability to rethinking the framing of issues and problems in such a way that those subject to them are able to escape their frame. It is a form of escape that is being offered, an escape from the picture which 'held us captive'. Wittgenstein's comment, in full, is that 'A picture held us captive. And we could not get outside it, for it lay in our language and language seemed to repeat it to us inexorably'. ${ }^{16}$ Where incommensurability and incompatibility are profound there are limits to conceptualisation as the bases for conceptualisation are themselves in doubt. To misappropriate Schmitt's account of the sovereign: cognitive leader is he or she who can decide on the reconceptualisation.

\section{A Masked Crisis?}

If one walks in some part of Britain (near Hadrian's Wall for example) you can, on a summer day, clearly see not Roman roadways as such but tangible evidence of their path. Why are they visible only in the summer? Because they traverse what have been wheat fields for centuries and can only be seen when the wheat is ripening, when the wheat along the line of the paths is visibly shorter and flimsier than that surrounding it. The reason is that centuries ago the soil was repeatedly and heavily compacted by traffic, and, despite the intervening length of time, this affects crop growth today. One might 
compare this with the situation at the end of the First World War when the victors (as personified for example by Sir Mark Sykes, François Georges-Picot and Gertrude Bell) ${ }^{17}$ carved up the Middle East to their own purposes. Without claiming that all of the ills of the present Middle East can be attributed to these often arbitrary boundary divisions (which would be an illegitimate piece of historical determinism) there is no doubt that the way the boundaries were created left a legacy which is visible in the present, just as are the lines of the Roman roads. Many say that the troubles of the Middle East can (at least in part) be attributed to these decisions taken a hundred years ago. Can we say that there was a masked crisis (or perhaps a suppressed crisis) which emerged only many decades after it was first thought to have been attended to and dealt with?

In one sense, radical change can be easily brought about. It is apparently easy to carve up the post war world and resolve longstanding issues: or so it seemed. But culture, language, tradition, and political and tribal allegiances were only masked but not removed, and on their re-appearance they returned with a vengeance, with a force in some senses in direct proportion to the strength of their original denial. These things were held not to matter, hence they were treated as though they did not matter; but in the end Britain and other nations were forced to see just how much they had really mattered all along. The boundary divisions established at the end of the First World War were, one might say, a success, but a catastrophic success. ${ }^{18}$

This illustration points to the possible existence of a masked or suppressed crisis. But how do we characterise this? Is it a delayed crisis, a postponed crisis or a crisis that was always present although subterraneously? Is it a crisis that can be resolved and, if so, on what terms? There obviously cannot be a return to the status quo ex ante and neither can a remedy be found in a fresh round of neat boundary changes, the misplace belief in which was the essence of the problem in the first place. In social and political affairs going back to the past from the present is never really possible as the present always contains traces of the past incapsulated in itself. To coin a complicated phrase: a present which is what it is because it has reverted to a previous state of affairs is different from the original state of affairs to which it is reverting precisely because it is a reaction to the reaction to that original state of affairs. ${ }^{19}$ Hence there is, I suggest, a real possibility that here we have not only a masked or suppressed crisis, and that such a crisis remains a permanent crisis, its permanency guaranteed by the very factors which mistakenly led British rulers to believe (or affect to believe) that rationalistic constructions of the type that Oakeshott so memorably denounced ${ }^{20}$ were possible.

A masked or suppressed crisis is, then, a crisis which is (or was) not visible, was not a felt experience at the time of crisis, but nonetheless a real event, a real process, with real effects which we only discover later, retrospectively attributing them to a crisis invisible to us at the time. But this is, put like that, misleading: the crisis was felt by some - the powerless; it was unfelt only by the powerful, or those most distant from the locus of crisis.

\section{Tradition}

'Normal' politics or science takes place against a shared background of deeply held presuppositions constituting both the form and the content, both the substance and the method, of the forms of inquiry and activity. Such constellations of presuppositions, providing a background of intelligibility within which foreground activities and inquiries 
take place, slowly change and are subject to modification. This is a tradition. But traditions, on the Kuhnian account, can lead themselves into crises, which implies that they can be broken, and that the conditions of intelligibility can be shattered or seriously injured at least.

How do we understand what it might mean for a tradition to break? Is such a thing conceivable? Can there be a crisis in a tradition? Can a tradition collapse? Do crises take place within a tradition or mark a breakdown between traditions? Kuhn himself seems to be ambiguous on this point, arguing that a paradigm is a tradition because it grants intelligibility to the scientific project at any given time. ${ }^{21} \mathrm{He}$ is here using the term tradition in a narrow sense, and one which excludes the possibility of radical change. But is there any reason that radical change over time is excluded within a tradition? And even where there seems to be radical change, is there not some sense in which a wider background of shared practices and mutual intelligibilities aka tradition remains in place? If the former - does this violate the understanding of tradition as gradual development within which change takes place intelligibly against a background of shared but shifting presuppositions which overlap sufficiently for there to be no radical break? Does the idea of a break within a tradition make sense? Or can there be a break between traditions? Or should we conceive of traditions as continuing in ways deeper than the surface disturbances which are so alarming to those experiencing them at the time, as Oakeshott argues in some moods?22

But if crises mark a break between traditions, does it follow that a) tradition is constantly born de novo and b) that no meaning, or practices carry over from one to another? Logically, to assert the first position stated above, a difference between paradigms and tradition has to be presupposed. For example, the difference between science per se and a particular paradigm within science at a given time. Just as anomalies only make sense against the background of a paradigm, so a paradigm only makes sense against a background of science, that is, a particular tradition, per se. one could, of course, ask the bigger question, which is whether there can conceivably be a super crisis not just of a paradigm but of science itself? An example of such a claim appears to be that made by Alasdair MacIntyre in After Virtue, when he propounds his 'disquieting suggestion'.

The hypothesis which I wish to advance is that in the actual world which we inhabit the language of morality is in the same state of grave disorder as the language of natural science in the imaginary world which I described. What we possess, if this view is true, are the fragments of a conceptual scheme, plans which now lack those contexts from which their significance derived. We possess indeed simulacra of morality, we continue to use many of the key expressions. But we have-very largely, if not entirely-lost our comprehension, both theoretical and practical, of morality. ${ }^{23}$

Our problem here is that crises are precisely occasions on which the conditions of intelligibility breakdown and this seems to imply a break in tradition rather than a continuity. One answer is to distinguish between relatively deeper and relatively shallower presuppositions. It might be for example that a paradigm breaks down, but it does so against a background of an ongoing scientific tradition of practice and inquiry. After all, if the rupture were complete then it would be impossible even to identify any remedy or modification as belonging to the same genus. Everything changes, but not everything changes equally all the time. Intelligibility is never entirely lost; the conversation never fully disappears. On this view it would appear that MacIntyre overstated his case, and that we know that he overstated it because if it were really true 
the conditions of intelligibility for claiming its truth would be absent and hence his case could not be intelligibly made. But given that it was intelligibly made, it must follow, on this view that he overstated it. So perhaps he overstated the position - but this in itself could be the point: he clearly shows that we still possess fragments of the original moral tradition and hence he shows, by the same token, that the rupture is not complete.

One way to characterise MacIntyre's position is through using the concept introduced earlier - that of a masked crisis: that is, a crisis in which we do not typically appreciate that there is a crisis at all until circumstances emerge historically in which the crisis is revealed as having been present all along. This presupposes that a crisis does not have to be a felt crisis: a real crisis might or might not be a felt crisis and conversely, a crisis might be falsely felt, in which case there is a crisis not of substance but of confidence real in its way, but not structurally or conceptually challenging in the way that the crises discussed above are.

\section{Conclusion}

In the view stated in this paper, a crisis is in large measure a feature of strains arising within presuppositions themselves and between those presuppositions and our practices and consciousness of the foundations of those practices. Just now I asked whether a crisis can be a crisis if we do not know it to be so? There is a difficulty here: if, as suggested above, part of being a crisis is that we do not know the outcome, then a crisis has to be a felt crisis or it is no crisis. However, if the idea of a hidden or masked crisis has anything to be said for it, there are crises which are not felt crises (or are felt crises only at some later point, after the crisis has already been doing its subterranean work. But if it has to be felt as a crisis to be a crisis, this seems to rule out the possibility of a masked crisis. The distinction is between logical and psychological aspects of a crisis. A felt crisis is one experienced as a crisis; a masked crisis is one which is not felt (at the time) as a crisis, but which is nonetheless logically a crisis. Such a crisis will eventually be experienced as a crisis, but it is still a genuine crisis in the logical sense irrespective of whether it is experienced as such. We have to retain this distinction between experience of crisis and identification (logically) of a crisis, otherwise a crisis is simply what we experience as a crisis, and although the perception of a crisis can cause a crisis of sorts (to misappropriate Roosevelt, crisis lies in the fear of crisis itself) such a crisis is not what Kuhn is discussing, because it is not rooted in the logical and experimental features of a paradigm and its structuring presuppositions. In the end I am endorsing the dialectical thesis identified at the outset, despite temptations to overstate crisis and to render it both unintelligible and irresolvable.

James Connelly moved to the University of Hull in 2006, after having taught at the University of Southampton and Southampton Solent University. He teaches political theory, contemporary political philosophy and environmental politics. He also writes on the political philosophy of R.G. Collingwood and other British Idealists, on the philosophy of history, and on electoral systems and political participation. He was the Principal Investigator for the Leverhulme funded Military Ethics Education Network) MEEN (2009-12,) and is currently Principal Investigator for the ESRC funded project The Common Good: Ethics and Rights in Cybersecurity (ERCS). James is co-editor of the International Journal of Social Economics, and Collingwood and British Idealism Studies. 


\section{BIBLIOGRAPHY}

BARR James, A Line in the Sand: Britain, France and the Mastery of the Middle East,(London, Simon and Schuster, 2011).

BUTTERFIELD Herbert, The Whig Interpretation of History, (London, Bell, 1931).

ButTERFIELD Herbert, The Origins of Modern Science, (London, Bell, 1959).

COLLINGWOod Robin G., An Autobiography, (Oxford, Oxford University Press, 1939).

Collingwood Robin G., An Essay on Metaphysics, (Oxford: Clarendon Press 1940).

Collingwood Robin G., The Idea of Nature, (Oxford: Clarendon Press, 1945).

CollinGWood Robin G., The Idea of History, (Oxford: Clarendon Press, 1946).

ConNelly James, 'Coalition, Aviation and the Descent to 'Politics as Usual', in Sustainable Aviation

Futures, ed. BUDD Lucy, Griggs Steven and HowARTH David, (Bingley, Emerald, 2013).

CONNELly James, review of MATTHEWs Laurence and Alison, Framespotting <http://

www.globalpolicyjournal.com/blog/13/01/2015/book-review-framespotting-changing-how-youlook-things-changes-how-you-see-them>

KuHN Thomas S., The Structure of Scientific Revolutions, 4th ed. (Chicago, University of Chicago Press, 2012).

LEWIS Geoffrey, The Turkish Language Reform: A Catastrophic Success, (Oxford, Oxford University Press, 1999).

LUKES Steven, Power: A Radical View, 2nd rev. ed. (1974 repr. Basingstoke: Palgrave Macmillan, 2005).

MACINTYRE Alasdair, After Virtue (London, Duckworth, 1981).

MATTHEWS Laurence and Alison, Framespotting: Changing how you look at things changes how you see them (Alresford, Iff Books, 2014).

OAKESHOTT Michael, Rationalism in Politics (London, Methuen, 1962).

schmitT Carl, Political Theology (Cambridge Mass., MIT Press, 1985).

TORGERSON Douglas, ‘The Ambivalence of Discourse: Beyond the Administrative Mind?' In PAEHLKE Robert and TORGERSON Douglas (eds.) Managing Leviathan: Environmental Politics and the Administrative State, 2nd ed. (Peterborough, Ontario, Broadview Press, 2005).

WIITGENSTEIN Ludwig, Philosophical Investigations (Oxford, Blackwell, 1953).

\section{NOTES}

1. KUHN Thomas S., The Structure of Scientific Revolutions, 4th ed. (Chicago, University of Chicago Press, 2012). 
2. BUTTERFIELD Herbert, The Whig Interpretation of History (London, Bell, 1931), p.2.; The Origins of Modern Science (London, Bell, 1959).

3. Collingwood Robin G., An Essay on Metaphysics rev. ed. (1940; repr., Oxford, Clarendon Press, 1998); The Idea of Nature (Oxford, Clarendon Press, 1946); The Idea of History rev. ed.(1946; Oxford, Oxford University Press, 1993).

4. Collingwood Robin G., An Essay on Metaphysics, p. 74.

5. This is to ignore, as not relevant for present purposes, claims sometimes made within physics concerning the anthropic principle (in its various forms) that the world is ideally fitted for the development of beings able to understand it.

6. KUHN Thomas S., Structure of Scientific Revolutions, p. 37.

7. Collingwood Robin G., An Essay on Metaphysics, pp. 75-76.

8. This analysis is developed at greater length in James Connelly, 'Coalition, Aviation and the Descent to 'Politics as Usual', in Sustainable Aviation Futures, ed. Lucy BUDD, Steven GRIGGS and David HOWARTH, 2013, pp. 219-238.

9. Economic neo-liberalism is an example of 'politics as usual', but it covers assumptions made by many who would not consider themselves neo-liberals.

10. LUKES S., Power: A Radical View, $2^{\text {nd }}$ rev. ed. (1974;, repr. Basingstoke, Palgrave Macmillan, 2005).

11. TORGERSON Douglas, 'The Ambivalence of Discourse: Beyond the Administrative Mind?' In PAEHLKE Robert and TORGERSON Douglas (eds.), Managing Leviathan: Environmental Politics and the Administrative State, 2nd ed., (Peterborough, Ontario, Broadview Press, 2005).

12. TORGERSON Douglas, Ibid, p. 106.

13. For more on 'framing', see Laurence and Alison MATTHEws, Framespotting: Changing how you look at things changes how you see them, (Alresford, Iff Books 2014), and review by James CoNNELLY, http://www.globalpolicyjournal.com/blog/13/01/2015/book-review-framespotting-changinghow-you-look-things-changes-how-you-see-them

14. KUHN Thomas S., The Structure of Scientific Revolutions, p. 77.

15. sснмітт Carl, Political Theology (Cambridge Mass, MIT Press, 1985), p. 13.

16. WITTGENSTEIN Ludwig, Philosophical Investigations (Oxford, Blackwell, 1953), § 115.

17. BARR James, A Line in the Sand: Britain, France and the Mastery of the Middle East (London, Simon and Schuster, 2011).

18. The phrase is taken from LEWIS Geoffrey, The Turkish Language Reform: A Catastrophic Success (Oxford, Oxford University Press, 1999).

19. On the notion of incapsulation, see Collingwood Robin G., An Autobiography, rev. ed. (1939; repr. Oxford, Oxford University Press, 2013) pp. 98-100, 113-14, 137-146.

20. See the essays 'Rationalism in Politics', 'Rational Conduct' and 'Political Education' in OAKeSHOTT Michael, Rationalism in Politics (London, Methuen, 1962).

21. KuHN Thomas S., The Structure of Scientific Revolutions, p. 85.

22. It is important to distinguish the traditional from the idea of tradition. The latter I characterise as the condition of intelligibility for utterance and action; the former as a repeated habit, disposition or practice perceived as fixed and immutable. The traditional is epiphenomenal with respect to the conditions of intelligibility because it takes place against the background of a tradition. Hence traditions move (indeed, they are characterised by movement) and the traditional is something we repeat in perpetuity.

23. MACINTYRE Alasdair, After Virtue (London, Duckworth, 1981), p. 2. 


\section{ABSTRACTS}

This paper draws on Thomas Kuhn's The Structure of Scientific Revolutions, but it is neither an exposition nor a critique of that book and uses certain concepts from it as a springboard for reflections on the nature of crisis. Kuhn's key term was paradigm; however, the primary focus of this paper will be on the intertwined concepts of normal and revolutionary science, and one of the concepts central to the latter: crisis. I ask whether crisis necessarily constitutes a break in continuity or practice, together with our understanding of that practice, thereby generating an inability to 'think through' crisis (the radical rupture thesis), or whether crisis can be conceived in an evolutionary fashion as a dialectical progression in which tensions and oppositions do not necessarily signify (or result in) a breakdown of the system or our understanding of it (the dialectical thesis). One of the underlying questions to be considered is precisely how far the analogy between natural science and politics is valid. Here my purpose is primarily to explore the issue and to raise questions rather than to provide concrete answers.

Cet article prend appui sur l'ouvrage de Thomas Kuhn La structure des révolutions scientifiques. Sans en proposer une présentation ni une critique, il reprend certains des concepts auquel recourt l'auteur pour interroger la nature de la crise. Si, chez Kuhn, le « paradigme » constitue un termeclé, il s'agira ici en premier lieu d'examiner les concepts, qui se recoupent, de science normale et de science révolutionnaire, et, dans ce dernier cas, celui de crise, qui lui est central. On se demandera si la crise doit se concevoir nécessairement comme rupture d'une continuité et d'une pratique, ainsi que de la manière même dont nous comprenons cette pratique - ce qui, selon la thèse de la rupture radicale, nous rendrait incapables penser une résolution de la crise -, ou bien si elle doit être envisagée en termes d'évolution et dans la perspective d'une progression dialectique : les tensions et les oppositions ne signifieraient ni n'entraîneraient automatiquement la fin du système, pas plus que notre manière de l'appréhender (thèse de la dialectique). Parmi les questions sous-jacentes qui se posent, il conviendra d'examiner dans quelle mesure on peut établir une analogie entre sciences naturelles et politique. On s'efforcera ici avant tout de tenter de poser le problème et de soulever des interrogations plutôt que de fournir des réponses concrètes.

\section{INDEX}

Mots-clés: Kuhn, Collingwood, crise, tradition, raison, politique ordinaire

Keywords: Kuhn, Collingwood, crisis, tradition, reason, normal politics

\section{AUTHOR}

\section{JAMES CONNELLY}

University of Hull 